\title{
The determination of food sources for invertebrates in four ponds in NW Spain using stable isotope analysis
}

\author{
Cesar J. Benetti*, Amaia Pérez-Bilbao and Josefina Garrido \\ Department of Ecology and Animal Biology, Faculty of Biology, University of Vigo, Campus As Lagoas \\ Marcosende, 36310, Vigo, Spain. \\ * Corresponding author: cjbenetti@uvigo.es
}

Received: $15 / 07 / 2013 \quad$ Accepted: $12 / 02 / 2014$

\begin{abstract}
The determination of food sources for invertebrates in four ponds in NW Spain using stable isotope analysis

This study assessed riparian vegetation as a source of energy in different ponds. The trophic importance of food sources from the riparian zones for invertebrate consumers was analysed using the dual stable isotope technique. We measured stable carbon $\left(\delta^{13} \mathrm{C}\right)$ and nitrogen $\left(\delta^{15} \mathrm{~N}\right)$ isotope values for three energy sources and primary consumers in four ponds in NW Spain to determine food sources that support primary consumers. Samples of littoral macroinvertebrates, macrophytes, epiphyton, and riparian vegetation were collected during two periods (summer 2010 and summer 2011) at each site. We used the MixSIR Bayesian mixing model to model the contribution of potential food sources of organic carbon supporting primary consumers at the study sites. The $\delta^{13} \mathrm{C}$ signatures of food sources varied between $-35.5 \%$ and $-20.76 \%$, whereas the $\delta^{15} \mathrm{~N}$ signatures ranged from $-6.2 \%$ to $11.27 \%$. Primary consumer isotope signatures corrected for the discrimination factor were within the range of the isotope values of the potential food sources in three of the ponds. Significant differences were observed in $\delta^{13} \mathrm{C}$ and $\delta^{15} \mathrm{~N}$ signatures among sources at each site and overall $(p<0.05)$. Significant differences were also found among sampling sites for each source separately and for overall food sources $(p<0.05)$. The MixSIR Bayesian stable isotope mixing model indicated that riparian vegetation and epiphyton were the most important production sources supporting the biomass of invertebrates overall. In addition, riparian vegetation and epiphyton were, most likely, a food source in the three ponds. Macrophytes were an unlikely food source for invertebrates in all ponds, although they could have some importance as a source in the Bodeira pond.
\end{abstract}

Key words: Food sources, invertebrates, primary consumers, ponds, isotopes, MixSIR, Spain.

\section{RESUMEN}

Determinación de las fuentes de alimento para invertebrados en cuatro lagunas en el noroeste de España mediante el análisis de isótopos estables

Este estudio evaluó la vegetación marginal como fuente de energía en diferentes lagunas. La importancia trófica de las fuentes de alimentos provenientes de la zona marginal para los invertebrados consumidores fue analizada mediante la técnica de isótopos estables. Medimos los valores de los isótopos estables de carbono $\left(\delta^{13} C\right)$ y nitrógeno $\left(\delta^{15} N\right)$ de tres fuentes de energía y consumidores primarios en cuatro lagunas en el noroeste de España para determinar las fuentes de alimento que soportan los consumidores primarios. Las muestras de macroinvertebrados litorales, macrófitas, epifiton y vegetación marginal se recogieron durante dos períodos (verano de 2010 y verano de 2011) en cada punto. Se utilizó el modelo de mezcla bayesiano MixSIR para modelar las potenciales fuentes de alimentos de carbono orgánico que dan soporte a los consumidores primarios en los puntos estudiados. Los valores de $\delta^{13} \mathrm{C}$ de las fuentes de alimentos variaron entre -35.5 \%o $y-20.76 \%$, mientras que firmas de $\delta^{15} \mathrm{~N}$ oscilaron entre $-6.2 \%$ a $11.27 \%$. Las firmas de isótopos de los consumidores primarios, corregidas por el factor de discriminación, estuvieron dentro del rango de los valores de isótopos de las fuentes potenciales de alimento en tres de las lagunas. Se observaron diferencias significativas en las firmas de $\delta^{13} \mathrm{C}$ y $\delta^{15} \mathrm{~N}$ entre las fuentes en cada punto y en global ( $\mathrm{p}<0.05$ ). También se encontraron diferencias significativas entre los puntos de muestreo para cada fuente por separado y en el conjunto de fuentes de alimento ( $\mathrm{p}<0.05$ ). El modelo de mezcla Bayesiano MixSIR indicó que la vegetación marginal y el epifiton fueron las fuentes de carbono más importantes que utilizan los consumidores primarios en el conjunto de lagunas. Además, estuvieron ligadas a los consumidores primarios en tres de las lagunas. Las 
macrófitas no estuvieron ligadas como fuente de alimento para los invertebrados en ninguna laguna, aunque podrían tener cierta importancia como recurso para la laguna de Bodeira.

Palabras clave: Fuentes de alimento, invertebrados, consumidores primarios, lagunas, isótopos, MixSIR, España.

\section{INTRODUCTION}

Ponds are systems of high biodiversity and productivity (Mitsch \& Gosselink, 2000). Their small size, coupled with their great abundance, means that these water bodies have a critical role to play in the global carbon cycle, as collectively they most likely trap significantly more carbon than the world's oceans (Downing et al., 2008). Although they form a significant part of the world's continental freshwater resources, ponds have long been overlooked in studies of the management and conservation of freshwater resources in comparison with running water and larger water bodies (Oertli et al., 2009).

Lakes, ponds, and wetlands that are characterised by strong environmental gradients (depth, shoreline, water current, or climate) exhibit corresponding variations in food web structure (March \& Pringle, 2003; Bucci et al., 2007; Abrantes \& Sheaves, 2008). Food webs are dynamic in space and time, and their structure can change in response to environmental drivers, species interactions, or a combination of these factors (Woodward \& Hildrew, 2002; De Ruiter et al., 2005). Because it has been estimated that littoral production might be equal to or greater than pelagic production in shallow lakes (Vadeboncoeur et al., 2002; Vander Zanden et al., 2006), a better knowledge of littoral macroinvertebrate food webs is thus necessary for better characterising food webs in entire water bodies. Nevertheless, we have little understanding of the energy dependence patterns of littoral invertebrates (Glaz et al., 2012).

Aquatic invertebrates have long been viewed as a critical link between primary producers and higher trophic levels in fresh waters (Wissinger, 1999, Hart \& Lovvorn, 2002). They contribute to decomposition and nutrient availability (Ruetz III et al., 2002; Kelly et al., 2004) and are important food sources for fish and other vertebrates (Taylor et al., 1999; Webb \& Mitsch, 2001). However, invertebrates are often not considered in detail at the community or ecosystem level in studies of standing waters (Battle \& Golladay, 2001), and their roles remain poorly understood in these ecosystems.

Stable isotope analysis is an important tool in the study of ecological food webs (Allen et al., 2005; Walter et al., 2006). They are considered to be steady, time-integrated tools for analysing the effective assimilation of dietary items in organisms (Post, 2002). The technique utilises the fact that consumers ingest the elements present in their food sources (Parnell et al., 2013). Stable isotope mixing models analyse the consumer animal's tissues (the mixture) and its potential diet (the sources) to quantify the relative contributions of isotopically distinct dietary components (Erhardt \& Bedrick, 2013), thus providing many benefits in comparison with traditional methods (Hobson \& Wassenaar, 2008).

Stable carbon $\left(\delta^{13} \mathrm{C}\right)$ and nitrogen $\left(\delta^{15} \mathrm{~N}\right)$ isotope analysis have long been widely used to study carbon transfer dynamics and food web structure in freshwater lacustrine ecosystems around the world (e.g., Campbell et al., 2003; Herwig et al., 2004). In addition, stable isotope analysis (SIA) is a powerful tool for identifying the food sources of consumers in complex lacustrine food webs (Yoshii, 1999), especially within littoral food webs, in which there are three major food sources: benthic algae, phytoplankton, and terrestrial organic matter derived from riparian zones (Karube et al., 2010).

Stable isotope mixing model (SIMM) analysis is an increasingly common approach in environmental sciences (Ward et al., 2011). Ecologists use mixing models to determine the pro- 
portional contribution of sources to a mixture (Phillips \& Koch, 2002; Phillips \& Gregg, 2003). Furthermore, SIMM can estimate the assimilated diet of an individual or a group of individuals (Phillips, 2012).

A number of recent papers have proposed Bayesian models to analyse isotope data (Moore \& Semmens, 2008; Cole \& Solomon, 2012; Jackson et al., 2013; Parnell et al., 2013; Soto et al., 2013). Bayesian models allow users to incorporate variability in trophic discrimination factors $\left(\delta^{13} \mathrm{C}\right.$ or $\left.\delta^{15} \mathrm{~N}\right)$ or the amount of change in either $\delta^{13} \mathrm{C}$ or $\delta^{15} \mathrm{~N}$ between prey and consumer (Bond \& Diamon, 2011). The advantages of these models compared with previous approaches include the possibility of incorporating variation in diet-tissue trophic discriminations (McCutchan et al., 2003) and prior information (Semmens et al., 2009; Ward et al., 2010; Ward et al., 2011). Bayesian mixing models also represent a powerful tool for obtaining reliable results because they can incorporate sources of variability in the interpretation of the data. Moreover, the model can be applied at both the population and the individual levels to trace the links of complex food webs (Soto et al., 2013).

In this study, we focused on the relative importance of various food sources in supporting primary consumption by the littoral invertebrate community in four ponds with different environmental characteristics. We aimed to (1) determine the sources supporting littoral macroinvertebrate

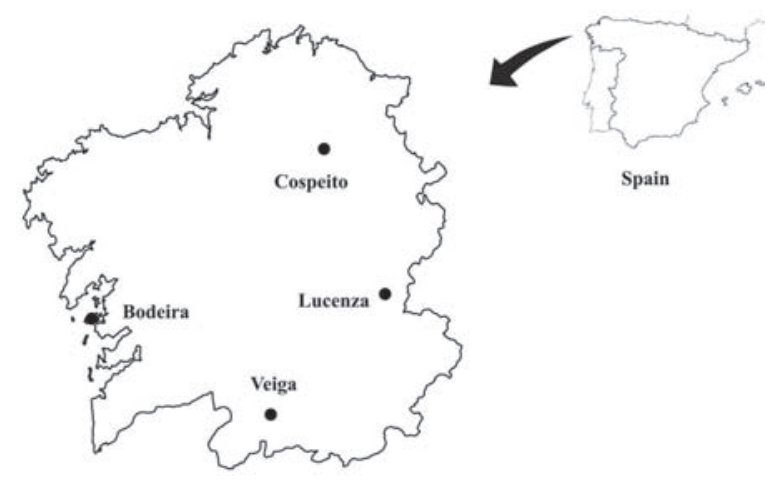

Figure 1. Geographical location of the study area. Spain and Galicia detail showing the four studied ponds. Localización geográfica del área de estudio. Detalle de España y Galicia donde se puede ver las cuatro lagunas estudiadas. communities in the different ponds and (2) assess the relative contribution of riparian vegetation as a source of energy for primary consumers.

Our hypotheses were that riparian sources would contribute significantly to energy input in the studied ponds and that the different ponds would show different patterns according to the importance of the contributions of the riparian food source. To test these hypotheses, we examined the stable isotope ratios of carbon and nitrogen in three potential food sources (riparian vegetation, macrophytes, and epiphyton) and primary consumers (littoral macroinvertebrates).

\section{MATERIALS AND METHODS}

\section{Study area}

This study was conducted in four ponds located in the Autonomous Community of Galicia, NW Spain (Fig. 1). All of them are protected under the Natura 2000 network within the Special Areas of Conservation (SAC). The climate in the area ranges from temperate hyper-oceanic subMediterranean to Mediterranean pluvioseasonal oceanic (Rivas-Martínez et al., 2004). In general, the climate is characterised as warm temperate, with dry summers and mild temperatures. The landscape near the ponds consists primarily of a mosaic of farmland, heathlands, and forests. All of the water bodies have substantial riparian vegetation that consists primarily of autochthonous deciduous trees, as well as significant macrophyte cover (Table 1). The main riparian vegetation and macrophyte species of each pond are shown in Table 2.

It is difficult to apply the same name to all types of standing water systems, especially due to the wide range of water surface areas. In this study, we refer to such systems as ponds, although pond systems do not usually include water bodies over five hectares (Oertli et al., 2009). The studied ponds (Table 1) have different environmental characteristics and different habitats according to Annex I of the European Union Habitats Directive (Directive 1992/43/EEC, 1992). Bodeira is a permanent coastal lagoon, although 
it may run out of water in very dry years. It has two different habitat types (numbers represent the Habitats Directive code): 1150 (Coastal lagoon) and 3150 (Natural eutrophic lakes with Magnopotamion or Hydrocharition-type vegetation). Cospeito is a permanent inland pond with a large water volume. It has two habitat types: 3130 (Oligotrophic to mesotrophic standing waters with Littorelletea uniflorae and/or IsoëtoNanojuncetea vegetation) and 3150 (see above). Veiga is a shallow temporary wetland with only one habitat: 3170 (Mediterranean temporary ponds). Lastly, Lucenza is a permanent mountain pond, although it may run out of water in very dry years. It has one habitat: 3160 (Natural dystrophic lakes and ponds).

\section{Sampling}

Pelagic and littoral zone primary producers show a differential uptake of isotopes (Jones et al., 2004; Finlay \& Kendall, 2007). This study focused on potential food sources for primary consumers in littoral zones. Thus, we analysed two aquatic sources (epiphyton and macrophytes) as well as the vegetation of the riparian zone (shoreline).

Components of the food web were sampled twice in summer 2010 and summer 2011. In 2011, only Bodeira and Cospeito were sampled because Lucenza and Veiga ran out of water at the time of sampling due to an unusual spring drought. In each survey, three replicate samples of the potential food sources and primary consumers were taken along the littoral zone of the water body and on the surrounding shoreline of the sampling sites. Additionally, we measured different physicochemical and habitat variables at each sampling site. For the physicochemical variables, three replicates were taken at each sampling time using a MultiLine F/S-3 multi-parameter meter system. Coordinates and altitude were measured with a Garmin GPS 12, and area was measured using a SIGPAC application. The percentage of riparian vegetation and macrophyte cover was estimated by direct observation in the field.

To assess potential riparian inputs to the ponds, riparian vegetation samples were collected by hand from the shores of the water bodies. Leaves were clipped, placed in plastic bags, and frozen for later processing. We established two potential aquatic food sources for littoral invertebrates from the studied ponds: epiphyton (attached layer of algae on the submersed surfaces of emergent and submersed macrophytes) and macrophytes (free-floating, submersed and emergent plants). Macrophytes were collected by hand. Leaves and stems were cut and washed several times to remove detrital matter, placed in plastic bags, and refrigerated.

Table 1. UTM coordinates and characteristics of sampling sites, with physicochemical and habitat variables. Variable ranges correspond to mean replicates. Coordenadas UTM y características de los puntos de muestreo, además de las variables físicoquímicas y descriptoras del hábitat. Los rangos de las variables corresponden a la media de las réplicas.

\begin{tabular}{|c|c|c|c|c|}
\hline Parameter & Bodeira & Cospeito & Lucenza & Veiga \\
\hline Code & $\mathrm{BO}$ & $\mathrm{CO}$ & LU & VE \\
\hline UTM X & 507966 & 617493 & 654794 & 594592 \\
\hline UTM Y & 4703605 & 4788987 & 4717389 & 4655111 \\
\hline Altitude (m.a.s.l.) & 11 & 407 & 1380 & 625 \\
\hline Area $\left(m^{2}\right)$ & 8000 & 56000 & 3600 & 1800 \\
\hline Dominant Substrate & $\mathrm{mud} / \mathrm{sand}$ & mud & mud & $\mathrm{mud} / \mathrm{sand}$ \\
\hline Riparian vegetation cover $(\%)$ & 50 & 100 & 80 & 30 \\
\hline Macrophytes cover $(\%)$ & 90 & 60 & 100 & 100 \\
\hline Trophic classification & eutrophic & mesotrophic/eutrophic & dystrophic & oligotrophic \\
\hline $\mathrm{pH}$ range & $7.0-8.2$ & $6.2-7.0$ & $5.7-7.0$ & 5.5-6.4 \\
\hline Oxygen range (mg/L) & $4.3-9.7$ & $2.4-6.8$ & $6.5-7.7$ & $1.3-6.9$ \\
\hline Conductivity range $\left(\mu \mathrm{Scm}^{-1}\right)$ at $20^{\circ} \mathrm{C}$ & 291-390 & $51-65$ & $12-15$ & $46-50$ \\
\hline Water temperature range $\left({ }^{\circ} \mathrm{C}\right)$ & $26.7-29.8$ & $18.4-23.1$ & $24.3-25.2$ & $18.1-19.2$ \\
\hline
\end{tabular}


Epiphyton samples were collected from the macrophytes (leaves and branches), and their surfaces were scraped and gently rinsed with water (after Huryn et al., 2001). The samples were filtered onto pre-combusted $\left(450^{\circ} \mathrm{C}\right.$ for $24 \mathrm{hr}) \mathrm{MFV} 5 ; 0.7 \mu \mathrm{m}$ ) filters, placed in zip lock bags and refrigerated for later analysis.

Macroinvertebrates were collected using a sweep net along the shoreline. Sampling was time-limited, with one minute of total sampling time for each pond. The sampled invertebrates were identified at the family level in the field. Primary consumers for the isotope analyses were selected based on previous studies (Merritt \& Cummins, 1996; Tachet et al., 2002). We selected the invertebrates for the stable iso- tope analysis by considering the proportion of the different trophic groups in each pond (see Figure 2). Selected invertebrates were collected alive, placed in bottles, and transported to the laboratory. The non-selected invertebrates were preserved in $99 \%$ ethanol. At the laboratory, they were sorted, identified at the family level for the study of functional feeding groups, and deposited in the Aquatic Entomology Lab collection of the University of Vigo.

\section{Sample processing}

All samples were stored on ice in the field and immediately processed upon arrival at the laboratory. The filters were examined under high

Table 2. Principal riparian vegetation and macrophyte species of Bodeira, Cospeito, Lucenza, and Veiga ponds observed in 2010 and 2011 samples. Principales especies de la vegetación marginal y macrófitas de las lagunas Bodeira, Cospeito, Lucenza y Veiga observadas en los muestros de 2010 y 2011.

\begin{tabular}{|c|c|c|c|c|c|}
\hline Vegetation & Species & BO & $\mathrm{CO}$ & $\mathbf{L U}$ & VE \\
\hline \multirow[t]{9}{*}{ Riparian } & Alnus glutinosa (L.) Gaertn. & $\mathrm{X}$ & $\mathrm{X}$ & $\mathrm{X}$ & $\bar{X}$ \\
\hline & Betula alba $\mathrm{L}$. & & $\mathrm{X}$ & $\mathrm{X}$ & \\
\hline & Erica sp. & & & & $\mathrm{X}$ \\
\hline & Eryngium viviparum J. Gay & & & & $\mathrm{X}$ \\
\hline & Fraxinus excelsior $\mathrm{L}$. & $\mathrm{X}$ & & $\mathrm{X}$ & $\mathrm{X}$ \\
\hline & Quercus robur $\mathrm{L}$. & & $\mathrm{X}$ & & $\mathrm{X}$ \\
\hline & Salix atrocinerea Brot. & $\mathrm{X}$ & $\mathrm{X}$ & $\mathrm{X}$ & $\mathrm{X}$ \\
\hline & Ulex europeaeus $\mathrm{L}$. & & & $\mathrm{X}$ & \\
\hline & Ulmus sp. & $\mathrm{X}$ & & & \\
\hline \multirow[t]{20}{*}{ Macrophytes } & Agrostis sp. & & & & $\mathrm{X}$ \\
\hline & Callitriche palustris $\mathrm{L}$. & $\mathrm{X}$ & $\mathrm{X}$ & & $\mathrm{X}$ \\
\hline & Ceratophyllum demersum $\mathrm{L}$. & & $\mathrm{X}$ & & \\
\hline & Chara sp. & & & $\mathrm{X}$ & \\
\hline & Cyperus sp. & & & & $\mathrm{X}$ \\
\hline & Damasonium sp. & & & & $\mathrm{X}$ \\
\hline & Glyceria fluitans (L.) R. Br. & $\mathrm{X}$ & & & \\
\hline & Lemna sp. & & & $\mathrm{X}$ & \\
\hline & Luronium natans (L.) Raf. & & $\mathrm{X}$ & & \\
\hline & Myriophyllum sp. & $\mathrm{X}$ & $\mathrm{X}$ & & \\
\hline & Nuphar sp. & & $\mathrm{X}$ & & \\
\hline & Phragmites sp. & & $\mathrm{X}$ & & \\
\hline & Polygonum amphibium L. & $\mathrm{X}$ & & & \\
\hline & Potamogeton pusillus $\mathrm{L}$. & & $\mathrm{X}$ & & \\
\hline & Ranunculus peltatus Schrank & $\mathrm{X}$ & & & $\mathrm{X}$ \\
\hline & Scirpus lacustris (L.) Palla & $\mathrm{X}$ & $\mathrm{X}$ & $\mathrm{X}$ & $\mathrm{X}$ \\
\hline & Sparganium augustifolium Michx. & & & $\mathrm{X}$ & \\
\hline & Thypha latifolia $\mathrm{L}$. & & $\mathrm{X}$ & & \\
\hline & Utricularia vulgaris $\mathrm{L}$. & & & $\mathrm{X}$ & \\
\hline & Zannichellia palustris L. & $\mathrm{X}$ & & & \\
\hline
\end{tabular}


magnification to ensure that the sample contained primary producers. The macrophytes and riparian tree leaves were rinsed with distilled water to remove sediment and large particles of detritus and then examined under a microscope to remove small particles and microorganisms. Animals were sorted alive and cleaned after relaxation with $10 \% \mathrm{MgCl}_{2}$ (after Olabarria et al., 2009). Subsequently, all of the samples were dried at $60{ }^{\circ} \mathrm{C}$ for $48 \mathrm{~h}$ and then frozen $\left(-20^{\circ} \mathrm{C}\right)$. The filters were then scraped to remove the epiphyton, and the plant and animal samples were ground to a fine powder using a pestle and mortar. The samples were weighed (at least $5 \mathrm{mg}$ of sample) into tin capsules in preparation for the analysis of carbon and nitrogen isotopes.

\section{Analytical technique}

The carbon and nitrogen isotopic composition of the samples was determined using an MAT 253 stable isotope ratio mass spectrometer. The carbon and nitrogen isotope ratios were expressed in parts per thousand (\%o) in the delta notation $\delta^{13} \mathrm{C}$ and $\delta^{15} \mathrm{~N}$, where

$$
\delta X=\left[\left(R_{\text {sample }} / R_{\text {standard }}\right)^{-1}\right] \times 10^{3},
$$

with $R={ }^{13} \mathrm{C} /{ }^{12} \mathrm{C}$ for carbon and ${ }^{15} \mathrm{~N} /{ }^{14} \mathrm{~N}$ for nitrogen, and reported relative to the Vienna Pee Dee Belemnite standard (VPDB) for carbon and to air $\mathrm{N}_{2}$ for nitrogen. The precision of the overall preparation and analysis was $\pm 0.13 \%$ for both $\delta^{13} \mathrm{C}$ and $\delta^{15} \mathrm{~N}$.

\section{Data analysis}

As the data did not deviate significantly from a normal distribution (Kolmogorov-Smirnov test, $p>0.05)$, no prior transformation was needed. A MANOVA was used to test for differences in isotope signatures among food sources (dependent variables: $\delta^{13} \mathrm{C}$ and $\left.\delta^{15} \mathrm{~N}\right)$. Subsequent pairwise comparisons were made with a Tukey test. Spatial (among sites) and temporal (among years) differences in isotope signatures of food sources and primary consumers were analysed using a one-way ANOVA (dependent variables: $\delta^{13} \mathrm{C}$ and $\left.\delta^{15} \mathrm{~N}\right)$. The one-way ANOVA indicated that differences among years were not significant $(p>0.05)$ for $\delta^{13} \mathrm{C}$ and $\delta^{15} \mathrm{~N}$ values for all sites, sources, and invertebrates. Therefore, the 2011 Bodeira and Cospeito samples were considered replicates. To investigate the importance of each food source in the primary consumer diet, we generated scatterplots with the average $\delta^{13} \mathrm{C}$ and $\delta^{15} \mathrm{~N}$ signals for each pond.

We used the MixSIR Bayesian stable isotope mixing model (Moore \& Semmens, 2008) to estimate the relative contribution of potential food resources to the invertebrate diet. MixSIR is a Bayesian mixing model framework capable of including any number of sources. The model has been used in a number of field-based freshwater food web studies (Moore \& Semmens, 2008; Semmens et al., 2009; Ward et al., 2010; Ward et al., 2011; Bond \& Diamond, 2011; Jackson et al., 2013). MixSIR implements the SIR algorithm (sampling importance resampling) and generates thousands of independent samples from the posterior distribution of the estimated source contributions. The model also provides the opportunity to incorporate prior information about the proportional contribution of each source to the mix (e.g., gut contents).

We provided the model with $\delta^{15} \mathrm{~N}$ and $\delta^{13} \mathrm{C}$ isotope data for consumer (mixture data), mean and standard deviation (SD) values for food and mean and SD isotope fractionation values. Nitrogen and carbon values were corrected for trophic discrimination using the values $2.3 \%$ and $0.5 \%$, respectively (McCutchan et al., 2003).

\section{RESULTS}

\section{Functional feeding groups of the communities}

A total of 57581 macroinvertebrate individuals were identified, belonging to 45 families (Table 3). Macroinvertebrates were classified into different functional feeding groups according to the literature (Merritt \& Cummins, 1996; Nilsson, 1996, 1997; Tachet et al., 2002). Considering only the primary consumers, and 
Table 3. Relative abundance of macroinvertebrate families sampled in littoral zones of the studied ponds in 2010 and 2011 and classified into different functional feeding groups. DS = detritivore-shredders; HS = herbivore-shredders; CF = collector-filterers; CG $=$ collector-gatherers; $\mathrm{PR}=$ predators; $\mathrm{SC}=$ scrapers. Abundancia relativa de las familias de macroinvertebrados muestreados en las zonas litorales de las lagunas estudiadas en 2010 y 2011 y clasificados dentro de los diferentes grupos funcionales de alimentación. $D S=$ desmenuzadores detritívoros; HS = desmenuzadores herbivoros; $C F=$ colectores-filtradores; CG = colectores-recolectores; $P R=$ depredadores $; S C=$ raspadores .

\begin{tabular}{|c|c|c|c|c|c|}
\hline Taxon & Functional Group & BO & $\mathrm{CO}$ & $\mathbf{L U}$ & $\mathbf{V E}$ \\
\hline Aeshnidae & PR & 22 & 6 & & 29 \\
\hline Asellidae & DS & 1 & 18 & & 666 \\
\hline Baetidae & CG SC & 988 & 1126 & 5 & 90 \\
\hline Ceratopogonidae & PR & 6 & 480 & & 422 \\
\hline Chaoboridae & $\mathrm{PR}$ & 109 & 52 & & \\
\hline Chironomidae & CG SC HS PR & 1090 & 3144 & 790 & 1940 \\
\hline Coenagrionidae & PR & 17 & 1605 & & 865 \\
\hline Cordulegastridae & PR & & 5 & & 7 \\
\hline Cordullidae & PR & 5 & 20 & & 142 \\
\hline Corixidae & PR & 638 & 192 & 2 & 2185 \\
\hline Crambidae & HS & 36 & 34 & & 102 \\
\hline Culicidae & PR & 245 & 103 & 4 & 589 \\
\hline Dixidae & CF CG & 1 & 547 & & 5 \\
\hline Dryopidae & SC DS & 95 & 19 & 160 & 6 \\
\hline Dytiscidae & PR & 158 & 349 & 194 & 607 \\
\hline Elmidae & $\mathrm{SC}$ & 52 & 1 & & 16 \\
\hline Empididae & PR & & 6 & & 221 \\
\hline Erpobdellidae & PR & 42 & 147 & & 213 \\
\hline Gerridae & PR & 10 & 51 & 10 & 18 \\
\hline Glossiphonidae & PR & 192 & 195 & & \\
\hline Gyrinidae & PR & 5 & 2 & 1 & 6 \\
\hline Haliplidae & HS & 17 & 116 & & 137 \\
\hline Helophoridae & $\mathrm{SC}$ & 3 & 77 & 109 & 71 \\
\hline Hydraenidae & $\mathrm{SC}$ & 892 & 14 & & 222 \\
\hline Hydrochidae & $\mathrm{SC}$ & 4 & 49 & & 721 \\
\hline Hydrometridae & PR & 15 & & & 6 \\
\hline Hydrophilidae & DS HS & 1238 & 1033 & 17 & 2297 \\
\hline Lestidae & PR & 7 & 156 & 291 & 365 \\
\hline Libellulidae & PR & 10 & 11 & & 739 \\
\hline Limnephilidae & SC DS & & 547 & 4700 & 2119 \\
\hline Limoniidae & DS HS & & 25 & & \\
\hline Lymnaeidae & $\mathrm{SC}$ & 37 & 979 & & 270 \\
\hline Naucoridae & PR & 426 & 40 & & 52 \\
\hline Notonectidae & PR & 921 & 35 & 11 & 101 \\
\hline Pelobiidae & PR & 11 & 12 & & \\
\hline Physidae & $\mathrm{SC}$ & 4008 & 682 & & \\
\hline Planariidae & PR & & 3 & & \\
\hline Planariidae & PR & 23 & 181 & & \\
\hline Planorbidae & SC DS HS & 5040 & 477 & & 1345 \\
\hline Platycnemididae & PR & & & & 206 \\
\hline Pleidae & PR & 2345 & 78 & & 196 \\
\hline Sialidae & PR & & 5 & & \\
\hline Siphlonuridae & CG SC & & & & 60 \\
\hline Sphaeriidae & CF CG & 1014 & 675 & 8 & 1132 \\
\hline Vellidae & PR & 25 & 66 & & \\
\hline
\end{tabular}




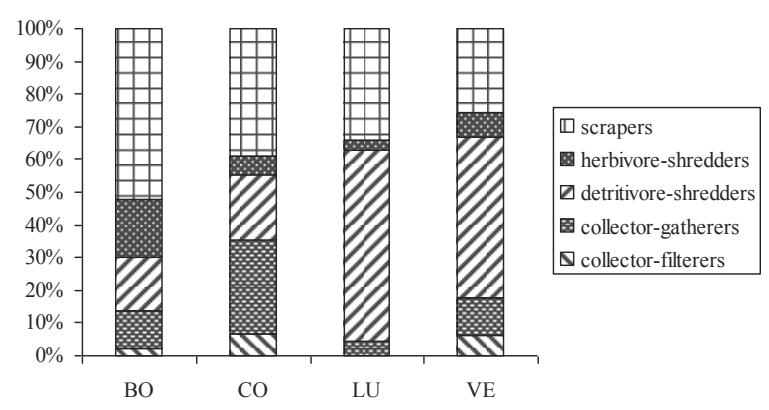

Figure 2. Proportion of each functional feeding group to all littoral macroinvertebrates in the studied ponds in 2010 and 2011 according to the total abundance of individuals. Proporción de cada grupo funcional de alimentación en el conjunto de macroinvertebrados litorales de las lagunas muestreadas en 2010 y 2011, de acuerdo a la abundancia total de individuos.

overall, scrapers were the main functional feeding group ( $40 \%$ of the total abundance), followed by detritivore-shredders $(32 \%)$, collector-gatherers $(14 \%)$, herbivore-shredders (10\%), and collector-filterers (4\%). However, if we analyse each pond, we find that the composition varied. In Lucenza and Veiga, for example, detritivore-shredders were the dominant group (58\% and $49 \%$ of the total abundance, respectively); in Cospeito, collector-gatherers were the second dominant group (29\% of the total abundance) after scrapers (39\%) (Fig. 2).

\section{Isotope signatures of potential food sources and primary consumers}

The mean $\delta^{15} \mathrm{~N}$ and $\delta^{13} \mathrm{C}$ values obtained for primary consumer and food sources of the four ponds are summarised in Table 4. Overall, visually comparing the stable isotope diagrams for each pond (Fig. 3), several marked differences can clearly be observed, especially in the source values among the ponds. Veiga tended to have higher $\delta^{15} \mathrm{~N}$ and $\delta^{13} \mathrm{C}$ values than the other ponds, and Bodeira tended to have lower $\delta^{15} \mathrm{~N}$ and $\delta^{13} \mathrm{C}$ values than the others. Riparian vegetation sources had lower $\delta^{15} \mathrm{~N}$ values than the other sources (macrophytes and epiphyton), but the $\delta^{13} \mathrm{C}$ values did not follow a clear pattern. The $\delta^{13} \mathrm{C}$ signatures of the food sources varied from $-35.5 \%$ to $-20.76 \%$, whereas the $\delta^{15} \mathrm{~N}$ signatures ranged from $-6.2 \%$ to $11.27 \%$ (Fig. 3).
Dual isotope analysis showed significant differences among sources at each site and overall (MANOVA, $p<0.05$ ). Pairwise comparisons showed significant differences between riparian and freshwater sources for both isotopic values at all sites (Tukey test, $p<0.05$ ). Among the sampling sites, we found significant differences for each source separately and for overall food sources $(p<0.01)$ for both isotopic values $(p<0.01)$.

Invertebrates had a $\delta^{13} \mathrm{C}$ range from $-34.83 \%$ to $-22.65 \%$ and a $\delta^{15} \mathrm{~N}$ range from $1.62 \%$ to $10.04 \%$. The dual plots showed that the isotopic composition of invertebrates, corrected for the discrimination factor, were within the range of the isotope values of the potential food sources in three of the ponds (Fig. 3).

\section{Linking invertebrates to their foods}

Figure 4 shows that the mixture (invertebrate isotope data) fell inside the convex polygon bounded by all sources in three of the ponds (Bodeira, Cospeito and Viega). Such an outcome can imply good solutions. In Lucenza, however, the mixture was outside the convex polygon, and no solution was possible. In addition, a MixSIR analysis for Lucenza gave a narrow range of results for all sources, suggesting that another unmeasured source could be the most likely food item.

Mixing model solutions $\left(5^{\text {th }}-95^{\text {th }}\right.$ percentile ranges) (Table 5) indicated that riparian vegetation and epiphyton were the most important production sources supporting invertebrate biomass overall. In addition, riparian vegetation and epiphyton were a relatively likely food source (range greater than $20 \%$ ) in the three ponds where the mixing model provided a feasible solution. In contrast, the Bayesian mixing model indicated that macrophytes were unlikely as food in all ponds, although they may have some relevance in Bodeira.

A MixSIR analysis for Bodeira suggested that invertebrates were primarily consuming epiphyton (median: $54.7 \%$ ), followed by riparian vegetation (median: $26.2 \%$ ) and macrophytes (median: 18.0\%). For Cospeito, the analysis suggested that invertebrates consumed epiphyton 

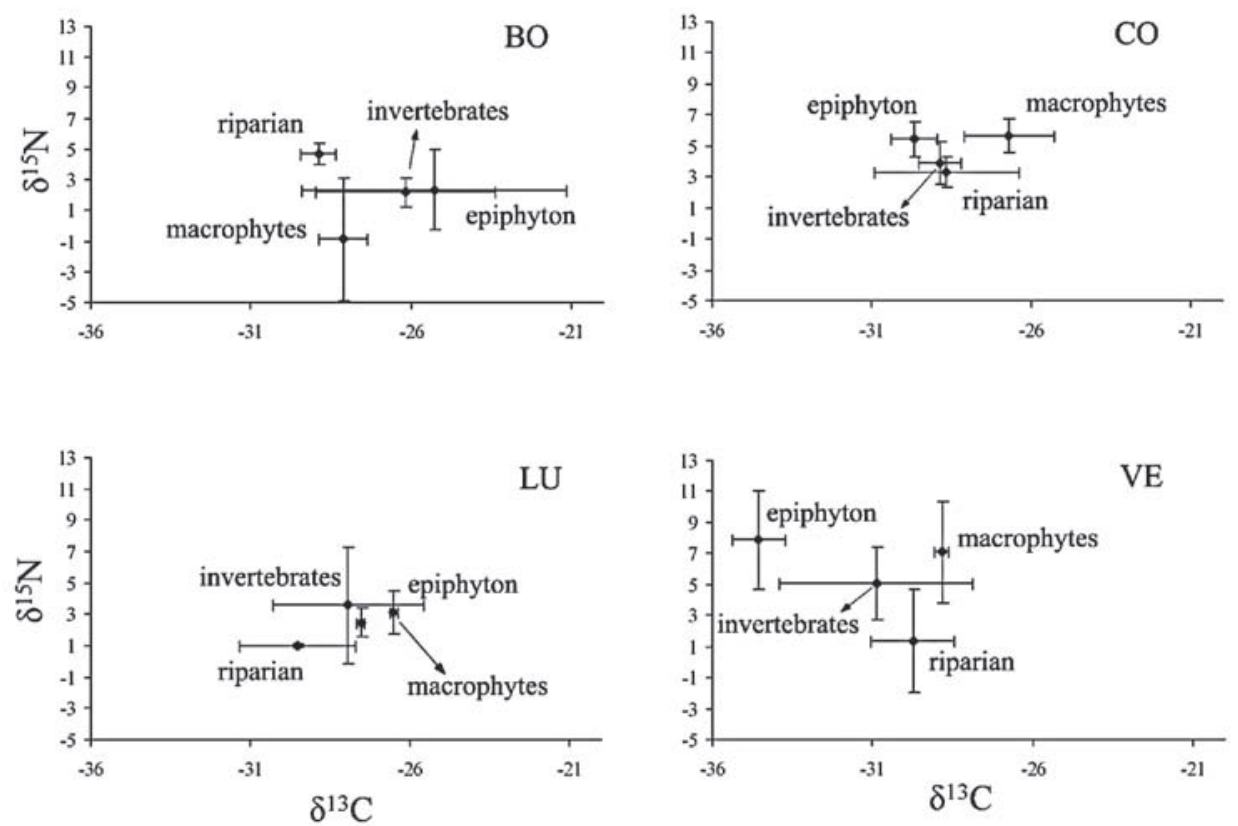

Figure 3. Dual isotopic composition biplots (replicates mean $\pm \mathrm{SE}$ ) of invertebrates and their potential food sources in each pond. Stable isotope data were corrected for trophic discrimination using the values of $2.3 \%$ and $0.5 \%$ for nitrogen and carbon, respectively (see Data Analysis). Diagramas de dispersión biespaciales de la composición isotópica (media de las réplicas media $\pm D E$ ) de los invertebrados y sus potenciales fuentes de alimento en cada laguna. Los valores de isotopos estables fueron corregidos por los coeficientes de fraccionamiento de $2.3 \%$ y $0.5 \%$, para nitrógeno y carbono, respectivamente.

(median: $61.3 \%$ ) and riparian vegetation (36.2\%), whereas macrophytes (median: $1.8 \%$ ) were an unlikely food source. In Veiga, riparian vegetation (median: $75.7 \%$ ) and epiphyton (median: $20.5 \%$ ) were indicated as likely foods, and macrophytes (median: $2.7 \%$ ) were indicated as unlikely food for invertebrates.

\section{DISCUSSION}

A dual-stable isotope analysis coupled with the MixSIR Bayesian mixing model allowed us to infer the contributions of primary producers to invertebrate primary consumers in the littoral zone of the studied ponds. In this study, the isotopic

Table 4. Dual isotope signatures of $\delta^{13} \mathrm{C}$ and $\delta^{15} \mathrm{~N}(\% 0)$ (replicates mean \pm SE) of potential food sources and invertebrates from the studied ponds. Firmas de isótopos $\left(\delta^{13} \mathrm{C} y \delta^{15} \mathrm{~N}\right.$, media de las réplicas $\left.\pm \mathrm{DE}\right)$ de las potenciales fuentes de alimento e invertebrados de las lagunas estudiadas.

\begin{tabular}{llcccr}
\hline & Sources & BO & CO & LU & VE \\
\hline$\delta^{13} \mathrm{C}$ & & & & & \\
& Invertebrates & $-26.67 \pm 2.81$ & $-29.38 \pm 1.41$ & $-28.44 \pm 2.35$ & $-31.39 \pm 3.03$ \\
& Epiphyton & $-25.26 \pm 4.14$ & $-29.66 \pm 1.11$ & $-26.51 \pm 0.14$ & $-34.56 \pm 0.83$ \\
& Macrophytes & $-28.12 \pm 0.74$ & $-26.69 \pm 1.09$ & $-27.54 \pm 0.11$ & $-28.85 \pm 0.23$ \\
& Riparian vegetation & $-28.9 \pm 0.55$ & $-28.65 \pm 1.02$ & $-29.51 \pm 1.81$ & $-29.74 \pm 1.3$ \\
$\delta^{15} \mathrm{~N}$ & & & & & \\
& Invertebrates & $4.48 \pm 0.9$ & $6.21 \pm 0.67$ & $5.9 \pm 3.72$ & $7.35 \pm 2.34$ \\
& Epiphyton & $2.36 \pm 2.63$ & $5.44 \pm 0.7$ & $3.11 \pm 1.38$ & $7.87 \pm 3.17$ \\
& Macrophytes & $-0.86 \pm 3.99$ & $5.64 \pm 1.41$ & $2.49 \pm 0.88$ & $7.11 \pm 3.27$ \\
& Riparian vegetation & $4.73 \pm 0.69$ & $3.32 \pm 2.27$ & $0.97 \pm 0.09$ & $1.33 \pm 3.33$ \\
\hline
\end{tabular}


analysis of $\delta^{13} \mathrm{C}$ and $\delta^{15} \mathrm{~N}$ revealed that riparian vegetation and epiphyton were the predominant energy source for primary consumers. However, it is desirable for the consumer values to lie within the fuzzy convex hull of the sources (see Parnell et al., 2013). In our study, in three of the ponds (Bodeira, Cospeito and Veiga) and after correction for the discrimination factor, the invertebrate isotope data fell inside the convex polygon bounded by the sources, suggesting that the likely food sources had been successfully sampled. In Lucenza, however, the consumers lay outside the mixing polygon delimited by all of the potential sources, and no solution was possible (see Phillips, 2012). This outcome indicates that a key end-member source was lacking or that there were large differences in stoichiometry among food sources (Soto et al., 2013).

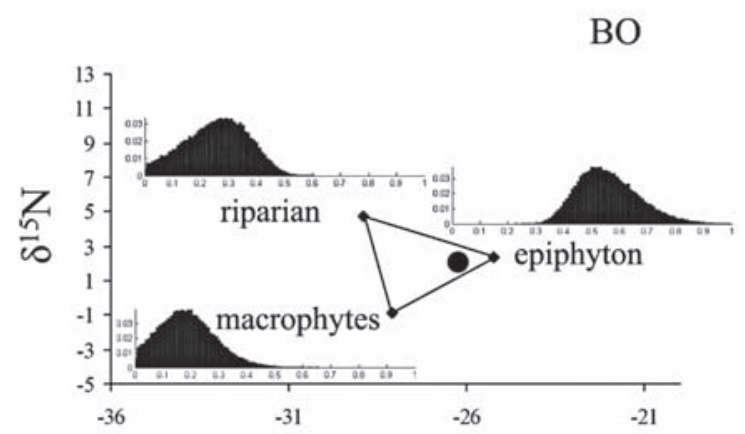

LU
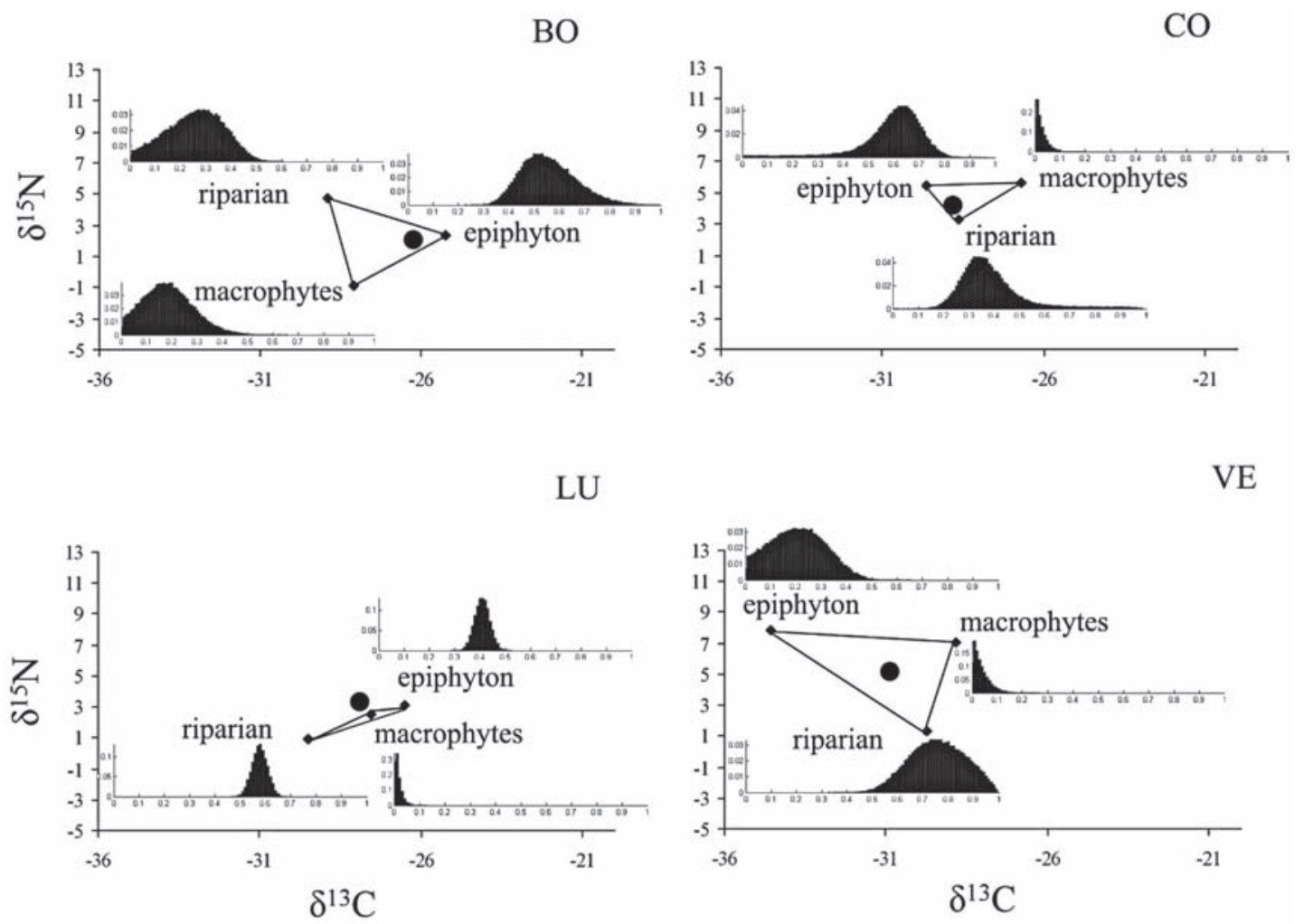

Compared with suspended phytoplankton, the periphyton complex plays a more significant role in most of the functional aspects of aquatic ecosystems, such as regulation of eutrophic conditions, maintenance of a two-dimensional stable nutrient resource flow, performing a nutrient retention and excess nutrient removal function, and indicating pollution and nutrient levels in the system as a whole (Saika, 2011). According to Biggs (1996), the attached algae often dominate algal biomass in shallow lakes. Most likely, more than $90 \%$ of all algal species grow attached to a substratum. Hart \& Lovvorn (2003) concluded that in the oligosaline and mesosaline wetlands they studied in Wyoming, USA, food webs were based mainly on microalgae. Similarly, Cremona et al. (2009) highlighted that epiphyton was the dominant source for macroinvertebrate
VE

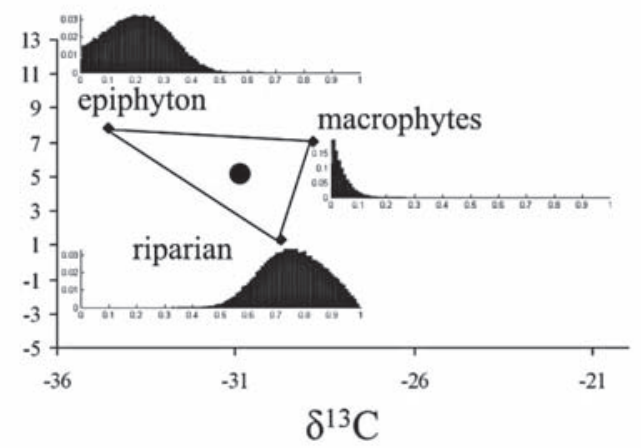

Figure 4. Posterior estimates of proportional contributions of food sources to invertebrates based on the MixSIR model. Each data point is the mean of the sample replicates. Circles represent invertebrates, and diamonds symbolise food sources. The histograms represent the distributions of posterior probabilities of source contributions to the invertebrates' diet. Estimaciones posteriores de la contribución proporcional de los recursos a los invertebrados, en base al modelo MixSIR. Cada punto es la media de las réplicas. Los círculos simbolizan los invertebrados y los rombos simbolizan las fuentes de alimentos. Los histogramas proporcionan la distribución de las contribuciones MixSIR de las fuentes a la dieta de los invertebrados. 
consumers at several sampling points in Lake St. Pierre, southern Quebec, Canada.

Various food web studies in aquatic environments have suggested a more dominant contribution from benthic algal food sources than from aquatic macrophytes (e.g., Bunn \& Boon, 1993). According to Hadwen \& Bunn (2005), periphyton carbon was the most significant food resource for aquatic consumers in the littoral zone of a lake in Australia, contributing between $48 \%$ and $70 \%$ of the carbon in consumer tissues overall, although riparian vegetation was important for certain groups of invertebrates such as crustaceans (60\% contribution). Similar results were obtained by Euliss et al. (1999) in research conducted in North Dakota (USA). They suggested that most invertebrates depended on carbon derived from microalgae, with a minor contribution from emergent, submersed, or floating macrophytes.

There are few reasons to expect low consumption of macrophytes. Hutchinson (1975) is quoted as supporting the idea that algae and bacteria are used by the macrophytes to "placate grazers" (Porter, 1977). In addition, macrophytes have high carbon-to-nitrogen ratios relative to most algae (Gregory, 1983). Additionally, certain macrophyte species are unpalatable to herbivorous animals because they are chemically defended against consumption (Dodds, 2002). According to Carpenter \& Lodge (1986), epiphytes are preferred over macrophytes because many aquatic grazers do not have mouth parts capable of puncturing or tearing macrophyte tissues (which are tough and low in nitrogen relative to periphyton), and/or macrophytes may be intrinsically unpalatable to many grazers. Although many aquatic herbivores consume only periphyton, there is abundant evidence that many grazers eat living macrophytes (Lodge, 1991). In addition, note that macrophyte tissue that is not consumed by herbivores enters the detrital food web upon senescence, so it is still possible that macrophytes contribute to consumer diets if detritus contains a high fraction of assimilable emergent carbon, as observed by Mann \& Wetzel (1996).

In contrast, submerged macrophytes would theoretically influence phytoplankton nutrient availability by boosting epiphyton and would additionally suppress phytoplankton by other mechanisms, such as allelopathy (Hilt \& Gross, 2008) and the provision of refuges to phytoplankton-grazing zooplankton (Timms \& Moss, 1984). Additionally, submerged macrophyte communities can play an important ecosystem function by increasing the available surface area for epiphyton production while positively influencing the light climate by reducing phytoplankton abundance through a variety of mechanisms (Hilt \& Gross, 2008). High invertebrate densities typically associated with macrophytes relative to other substrates (Lodge, 1985) may result from epiphyte food available on macrophyte surfaces (Sculthorpe, 1967). It is certainly true that many of the invertebrates associated with macrophytes eat the epiphyte-detritus complex on the surface of macrophytes rather than the macrophyte itself (Orth \& van Montfrans, 1984).

The principal mechanism by which riparian vegetation provides ponds with organic matter is the supply of falling leaves to form leaf litter. The decomposition of leaf litter is an essential ecosystem process in forested aquatic systems (Meyer et al., 1998), and its inputs are an important carbon source in lentic ecosystems (Wetzel, 2001; Rubbo et al., 2006, Rubbo et al., 2008). The quality of litter input for consumers

Table 5. Median and $5^{\text {th }}-95^{\text {th }}$ percentile ranges of source contributions to primary consumer biomass estimated by the MixSIR model. Medianas y percentiles 5-95 de las contribuciones de las fuentes de alimento a la biomasa de los consumidores primarios estimadas por el modelo MixSIR.

\begin{tabular}{|c|c|c|c|c|c|c|}
\hline \multirow[b]{2}{*}{ Pond } & \multicolumn{2}{|c|}{ Epiphyton } & \multicolumn{2}{|c|}{ Macrophytes } & \multicolumn{2}{|c|}{ Riparian vegetation } \\
\hline & Median & Percentile & Median & Percentile & Median & Percentile \\
\hline $\mathrm{BO}$ & 54.7 & $39.8-75.7$ & 18.0 & $3.4-36.4$ & 26.2 & $5.8-43.1$ \\
\hline $\mathrm{CO}$ & 61.3 & $29.6-74.5$ & 1.8 & $0.1-6.9$ & 36.2 & $23.3-67.9$ \\
\hline LU & 40.8 & $36.0-45.9$ & 1.0 & $0.1-4.4$ & 57.7 & $52.6-62.7$ \\
\hline VE & 20.5 & $3.3-39.1$ & 2.7 & $0.2-10.2$ & 75.7 & $57.6-93.2$ \\
\hline
\end{tabular}


depends on the species composition of the litter and the chemistry of the constituent species (Wetzel 2001, Swan \& Palmer 2006). According to Stoler \& Relyea (2011), different tree litter species can have substantial impacts on wetland communities because they can affect the density of phytoplankton, periphyton, and zooplankton, producing a change in wetland energy inputs.

Isotope analysis revealed clear differences in food sources among the studied ponds. These ponds have different nutrient concentrations (dystrophic, oligotrophic, mesotrophic, and eutrophic) that can have a major effect on aquatic community processes and may, consequently, produce variations in food web structure among ponds. Given the hydrologic, geomorphic, and taxonomic diversity of small standing water bodies worldwide, it is unlikely that a single conceptual model of carbon dynamics can apply to all ponds (Abrantes \& Sheaves, 2008).

Dystrophic lakes have a high content of humic organic matter. These systems, which receive large amounts of their organic matter supply from riparian sources, are commonly heavily stained and have been referred to as brown-water lakes. Under natural conditions, the relatively resistant humic substances of riparian plant origin represent one of the most common components of the organic matter in the water body (Wetzel, 2001). Lucenza, a dystrophic pond with substantial inputs of riparian organic matter, was one of the ponds in which the riparian vegetation was more important as a food source, in agreement with results obtained in other studies (e.g., Carpenter et al., 2005). In contrast, high phytoplanktonic primary productivity was also observed in dystrophic lakes (Nürnberg \& Shaw, 1998). We did not analyse phytoplankton in this study, but phytoplankton may be the missing unmeasured source that prevented the model from generating the appropriate solution, as indicated by the MixSIR analysis. Hence, it should be viewed as a possible food source in future studies in these systems.

Veiga is a temporary oligotrophic pond. The isotope analysis performed in this study suggested that in Veiga, invertebrates largely relied on riparian food sources, with algal food supplementing their diets. According to Wetzel (2001), the marginal vegetation growing adjacent to temporary ponds or the vegetation, including trees, growing within the ponds influences the loading of organic matter into the ecosystem. The predominant organic loading frequently occurs as dissolved organic matter leached from the riparian vegetation. In temporary ponds, particulate organic matter is primarily derived from trees via leaf fall and supports a significant portion of the overall metabolism of the pond (Hobbie, 1980). Similar findings have been obtained from other oligotrophic lakes, suggesting that littoral zone food webs are driven by riparian carbon through detritivorous pathways (Mancinelli et al., 2002). In Veiga, we observed the greatest contribution from riparian food sources, although Veiga is a pond with relatively little riparian vegetation cover. This result could indicate that the importance of riparian vegetation as an energy source is not correlated with the degree of vegetation cover.

Cospeito is a large permanent pond. Its trophic status changes from year to year, and it can be both mesotrophic and eutrophic (Ramil et al., 2006). In this study, the principal source supporting littoral invertebrates in this pond was epiphyton, followed by riparian vegetation, consistent with other studies that have highlighted the importance of epiphytic biomass as a food source in mesotrophic lakes (Schroeder et al., 2012). In this pond, riparian vegetation was also a likely food source. Leaf litter produced by riparian tree leaves that fall into the water is a primary food source for FPOM in many freshwater systems, as noted by several authors (e.g., Wetzel, 2001). In addition, leaf litter is the preferred habitat of collector-gatherers (Pope et $a l .$, 1999). These findings are consistent with our results; we observed that gatherers were an important feeding group in this pond, which has a very well developed riparian vegetation cover.

According to the isotopic analysis of the eutrophic coastal lagoon Bodeira, invertebrates had relatively broad food habits, suggesting a wide range of diets. Although the recurring theme was the presence of algae from epiphyton and, secondarily, tree leaves from riparian veg- 
etation, we should emphasise that macrophytes could also be an important food source. In this context, Brothers et al. (2013) have concluded that eutrophic shallow lakes with a submerged macrophyte-epiphyton complex may frequently support higher annual primary production than comparable lakes that contain only phytoplankton and periphyton. They have also suggested that the gross primary production (GPP) of small eutrophic shallow lakes is increased by the presence of a submerged macrophyte-epiphyton complex. In contrast, Gross et al. (2003) argue that epiphytes compete with macrophytes for light, carbon, and at certain times for nutrients; accordingly, in eutrophic lakes, their biomass increases and becomes the principal food source for the system.

Our results reflect the general trend shown by the invertebrate primary consumers, as we have not studied the isotopic signal of the various trophic groups separately. Nevertheless, the faunal composition data shed light on the trophic composition of the communities in the studied ponds. Note also that the various trophic strategies observed in each pond are consistent with the stable isotope analysis results, confirming that different primary consumer invertebrates have different isotopic values depending on the food source.

Based on a Bayesian mixing model of carbon and nitrogen stable isotope ratios, we were able to furnish the first estimates of food sources for invertebrates in the studied ponds. The model has demonstrated that the principal food sources driving food webs in the studied ponds were riparian vegetation and epiphyton. Thus, our findings highlight the importance of conserving riparian vegetation due to its importance as an energy source supporting aquatic food webs in ponds and as a structural and functional component of the ponds.

\section{ACKNOWLEDGEMENTS}

This research was supported by the Galician Autonomous Government through the Ministry of Economy and Industry (Project 09MDS
006310PR). Special thanks to Manoel Alexandre Justo Pérez and Jacobo Rúa Vila for their valuable assistance with sample collection.

\section{REFERENCES}

ABRANTES, K., \& M. SHEAVES. 2008. Incorporation of terrestrial wetland material into aquatic food webs in a tropical estuarine wetland. Estuarine Coastal and Shelf Science, 80: 401-412.

ALLEN, E. W., E. E. PREPAS, S. GABOS, W. M. L. STRACHAN \& W. ZHANG. 2005. Methyl mercury concentrations in macroinvertebrate and fish from burned and undisturbed lakes on the Boreal plain. Canadian Journal of Fisheries and Aquatic Sciences, 62: 1963-1977.

BATTLE, J. M. \& S. W. GOLLADAY. 2001. Water quality and macroinvertebrate assemblages in three types of seasonally inundated limesink wetlands in southwest Georgia. Journal of Freshwater Ecology, 16: 189-207.

BIGGS, B. J. F. 1996. Patterns in benthic algae of streams. In: Algal ecology. R. J. Stevenson; M. L. Bothwell \& R. L. Lowe (eds.): 31-56. Academic Press. San Diego. USA.

BOND, A. L. \& A. W. DIAMOND. 2011. Recent Bayesian stable-isotope mixing models are highly sensitive to variation in discrimination factors. Ecological Applications, 21 (4): 1017-1023.

BROTHERS, S. M., S. HILT, S. MEYER \& J. KÖHLER. 2013. Plant community structure determines primary productivity in shallow, eutrophic lakes. Freshwater Biology, 58: 2264-2276.

BUCCI, J. P., W. J. SHOWERS, S. REBACH, D. DEMASTER \& B. GENNA. 2007. Stable isotope analyses (delta N-15 and delta C-13) of the trophic relationships of Callinectes sapidus in two North Carolina estuaries. Estuaries and Coasts, 30: 1049-1059.

BUNN, S. E. \& P. I. BOON. 1993. What sources of organic carbon drive food webs in billabongs? A study based on stable isotope analysis. Oecologia, 96: 85-94.

CAMPBELL, L. M., R. E. HECKY \& S. B. WANDERA. 2003. Stable isotope analyses of food web structure and fish diet in Napoleon and Winam Gulfs, Lake Victoria, East Africa. Journal of Great Lakes Research, 29: 243-257. 
CARPENTER, S. R. \& D. M. LODGE. 1986. Effects of submersed macrophytes on ecossystem processes. Aquatic Botany, 26: 341-370.

CARPENTER, S. R., J. J. COLE, M. L. PACE, M. VAN DE BOGERT, D. L. BADE, D. BASTVIKEN, C. M. GILLE, J. R. HODGSON, J. F. KITCHELL, E. S. KRITZBERG. 2005. Ecosystem subsidies: terrestrial support of aquatic food webs from ${ }^{13} \mathrm{C}$ addition to contrasting lakes. Ecology, 86: 2737-2750.

COLE, J. J. \& C. T. SOLOMON. 2012. Terrestrial support of zebra mussels and the Hudson River food web: A multi-isotope, Bayesian analysis. Limnology and Oceanography, 57 (6): 1802-1815.

CREMONA, F., S. HAMELIN, D. PLANAS \& M. LUCOTTE. 2009. Sources of organic matter and methylmercury in littoral macroinvertebrates: a stable isotope approach. Biogeochemistry, 94: 81-94.

DE RUITER, P. C., V. WOLTERS, J. C. MOORE \& K. O. WINEMILLER. 2005. Food web ecology: playing Jenga and beyond. Science, 309: 68-71.

DIRECTIVE 1992/43/EEC 1992. Council directive 1992/43/EEC of the European Parliament and of the Council of 21 May 1992 on the conservation of natural habitats and of wild fauna and flora. Official Journal of the European Union, L206: $7-$ 50.

DODDS, W. K. 2002. Freshwater Ecology. Concepts and environmental applications. Academic Press. San Diego. USA.

DOWNING, J. A., J. J. COLE, J. J. MIDDELBURG, R. G. STRIEGL, C. M. DUARTE, P. KORTELAINEN, Y. T. PRAIRIE \& K. A. LAUBE. 2008. Sediment organic carbon burial in agriculturally eutrophic impoundments over the last century. Global Biogeochemical Cycles, 22: 1-10.

ERHARDT, E. B. \& E. J. BEDRICK. 2013. A Bayesian framework for stable isotope mixing models. Environmental and ecological statistics, 20: 377-397.

EULISS, N. H., D. A. WRUBLESKI \& D. M. MUSHET. 1999. Wetlands of the prairie pothole region: invertebrate species composition, ecology, and management. In: Invertebrates in freshwater wetlands of North America: ecology and management D. P. Batzer, R. B. Rader \& S. A. Wissinger (eds.): 471-51. Wiley, NY. USA.

FINLAY, J. C. \& C. KENDALL. 2007. Stable isotope tracing of temporal and spatial variability in organic matter sources to freshwater ecosystems.
In: Stable Isotope in Ecology and Environmental Science R. Michener \& K. Lajtha (eds.): 283-333. Blackwell, Malden. MA. USA.

GLAZ, P., P. SIROIS, C. NOZAIS. 2012. Determination of food sources for benthic invertebrates and brook trout Salvelinus fontinalis in Canadian Boreal Shield lakes using stable isotope analysis. Aquatic biology, 17: 107-117.

GREGORY, S. V. 1983. Plant-herbivore interactions in stream systems. In: Stream Ecology. J. R. Barnes \& G. W. Minshall (eds.): 157-189. Plenum Press. NY. USA.

GROSS, E. M., C. FELDBAUM \& A. GRAF. 2003. Epiphyte biomass and elemental composition on submersed macrophytes in shallow eutrophic lakes. Hydrobiologia, 506-509: 559-565.

HADWEN, W. L. \& S. E. BUNN. 2005. Food web responses to low-level nutrient and $15 \mathrm{~N}$-tracer additions in the littoral zone of an oligotrophic dune lake. Limnology and Oceanography, 50 (4): 10961105.

HART, E. A. \& J. R. LOVVORN. 2002. Interpreting stable isotopes from macroinvertebrate foodwebs in saline wetlands. Limnology and oceanography, 47: 580-584.

HART, E. A. \& J. R. LOVVORN. 2003. Algal vs. macrophyte inputs to food webs of inland saline wetlands. Ecology, 84 (12): 3317-3326.

HERWIG, B. R., D. A. SOLUK, J. M. DETTMERS, D. H. WAHL. 2004. Trophic structure and energy flow in backwater lakes of two large floodplain rivers assessed using stable isotopes. Canadian Journal of fisheries and aquatic sciences, 61: 12-22.

HILT, S. \& E. M. GROSS. 2008. Can allelopathically active submerged macrophytes stabilize clearwater states in shallow lakes? Basic and Applied Ecology, 9: 422-432.

HOBBIE, J. E. 1980. Limnology of Tundra ponds. Dowden, Hutchinson \& Ross Inc. Stroudsburg. PA. USA.

HOBSON, K. A., L. I. WASSENAAR. 2008. Tracking animal migration with stable isotopes. Academic Press. London. UK.

HURYN, A. D., R. H. RILEY, R. G. YOUNG, C. J. ARBUCKLE, K. PEACOCK \& G. LYON. 2001. Temporal shift in contribution of terrestrial organic matter to consumer production in a grassland river. Freshwater Biology, 46: 213-226. 
HUTCHINSON, G. E. 1975. A Treatise on Limnology. Vol. III. Limnological Botany. Wiley, NY. USA.

JACKSON, A. T., A. ADITE, K. A. ROACH, \& K. O. WINEMILLER. 2013. Primary production, food web structure, and fish yields in constructed and natural wetlands in the floodplain of an African river. Canadian Journal of Fisheries and Aquatic Sciences, 70: 543-553.

JONES, R. I., L. KING, M. M. DENT, S. C. MABERLY \& C. E. GIBSON. 2004. Nitrogen stable isotope ratios in surface sediments, epilithon and macrophytes from upland lakes with differing nutrient status. Freshwater Biology, 49: 382-391.

KARUBE, Z., Y. SAKAI, T. TAKEYAMA, N. OKUDA, A. KOHZU, C. YOSHIMIZU, T. NAGATA \& I. TAYASU, I. 2010. Carbon and nitrogen stable isotope ratios of macroinvertebrates in the littoral zone of Lake Biwa as indicators of anthropogenic activities in the watershed. Ecological research, 25: 847-855.

KELLY, A., R. I. JONES \& J. GREY. 2004. Stable isotope analysis provides fresh insights into dietary separation between Chironomus anthracinus and C. plumosus. Journal of the North American Benthological Society, 23: 287-296.

LODGE, D. M. 1985. Macrophyte-gastropod associations: observations and experiments on macrophyte choice by gastropods. Freshwater Biology, 15: 695-708.

LODGE, D. M. 1991. Herbivory on freshwater macrophytes. Aquatic Botany, 41: 195-224.

MANCINELLI, G., M. L. COSTANTINI \& L. ROSSI. 2002. Cascading effects of predatory fish exclusion on the detritus-based food web of a lake littoral zone (Lake Vico, central Italy). Oecologia, 133: 402-411.

MANN, C. J. \& R. G. WETZEL. 1996. Loading and utilization of dissolved organic carbon from emergent macrophytes. Aquatic Botany, 53: 61-71.

MARCH, J. G. \& C. M. PRINGLE. 2003. Food web structure and basal resource utilization along a tropical island stream continuum, Puerto Rico. Biotropica, 35: 84-93.

McCUTCHAN, J. H., JR., W. M. LEWIS, JR., C. KENDALL \& C. C. MCGRATH. 2003. Variation in trophic shift for stable isotope ratios of carbon, nitrogen and sulfur. Oikos, 102: 378-390.

MERRITT, R. W. \& K. W. CUMMINS. 1996. An introduction to the Aquatic Insects of North America. 3th ed. Kendall Hunt. Dubuque. IA. USA.
MEYER, J. L., J. B. WALLACE \& S. L. EGGERT. 1998. Leaf litter as a source of dissolved organic carbon in streams. Ecosystems, 1: 240-249.

MITSCH, W. J. \& J. G. GOSSELINK. 2000. Wetlands, third edition. John Wiley \& Sons, NY. USA.

MOORE, J. W. \& B. X. SEMMENS. 2008. Incorporating uncertainty and prior information into stable isotope mixing models. Ecology Letters, 11: 470480.

NILSSON, A. 1996. Aquatic insects of North Europe. A Taxonomic Handbook. Volume 1: Ephemeroptera, Plecoptera, Heteroptera, Neuroptera, Megaloptera, Coleoptera, Trichoptera, Lepidoptera. Apollo Books, Stenstrup. Denmark.

NILSSON, A. 1997. Aquatic insects of North Europe. A Taxonomic Handbook. Volume 2: Odonata, Diptera. Apollo Books, Stenstrup. Denmark.

NÜRNBERG, G. K. \& M. SHAW. 1998. Productivity of clear and humic lakes. Nutrients, phytoplankton, bacteria. Hydrobiologia, 382: 97-112.

OERTLI, B., R. CÉRÉGHINO, A. HULL \& R. MIRACLE. 2009. Pond conservation: from science to practice. Hydrobiologia, 634: 1-9.

OLABARRIA, C., M. INCERA, J. GARRIDO, I. F. RODIL \& F. ROSSI. 2009. Intraspecific diet shift in Talitrus saltator inhabiting exposed sandy beaches. Estuarine, Coastal and Shelf Science, 84: 282-288.

ORTH, R. J. \& J. van MONTFRANS. 1984. Epiphyte-seagrass relationships with an emphasis on the role of micrograzing: a review. Aquatic Botany, 18: 43-70.

PARNELL, A. C., D. L. PHILLIPS, S. BEARHOP, B. X. SEMMENS, E. J. WARD, J. W. MOORE, A. L. JACKSON, J. GREY, D. J. KELLY \& R. INGER. 2013. Bayesian stable isotope mixing models. Environmetrics, 24 (6): 387-399.

PHILLIPS, D. L. 2012. Converting isotope values to diet composition: the use of mixing models. Journal of Mammalogy, 93 (2): 342-352.

PHILLIPS, D. L., J. W. GREGG. 2003. Source partitioning using stable isotopes: coping with too many sources. Oecologia, 136: 261-269.

PHILLIPS, D. L. \& P. L. KOCH. 2002. Incorporating concentration dependence in stable isotope mixing models. Oecologia, 130: 114-125.

POPE, R. J., A. M. GORDON \& N. K. KAUSHIK. 1999. Leaf litter colonization by invertebrates in the littoral zone of a small oligotrophic lake. $\mathrm{Hy}$ drobiologia, 392: 99-112. 
PORTER, K. G. 1977. The plant-animal interface in freshwater ecosystems. American Scientist, 65: 159-170.

POST, D. M. 2002. Using stable isotopes to estimate trophic position: Models, methods, and assumptions. Ecology, 83: 703-718.

RAMIL, P., J. DOMÍNGUEZ, M. VIDAL, M. RUBINOS, C. CILLERO, I. ROMERO, M. A. RODRÍGUEZ, L. GÓMEZ-ORELLANA \& C. MUÑOZ. 2006. A lagoa de Cospeito. Consellería de Medio Ambiente e Desenvolvemento Sostible, Xunta de Galicia. Santiago. Spain.

RIVAS-MARTÍNEZ, S., A. PENAS \& T. E. DÍAZ. 2004. Bioclimatic and biogeographic maps of Europe. http://www.globalbioclimatics.org/form/maps. htm (accessed March 26, 2013).

RUBBO, M. J., J. J. COLE \& J. M. KIESECKER. 2006. Terrestrial subsidies of organic carbon support net ecosystem production in temporary forest ponds: evidence from an ecosystem experiment. Ecosystems, 9: 1170-1176.

RUBBO, M. J., L. K. BELDEN \& J. M. KIESECLER. 2008. Diff erential responses of aquatic consumers to variations in leaf-litter inputs. Hydrobiologia, 605: 37-44.

RUETZ III, C. R., R. M. NEWMAN \& B. VONDRACEK. 2002. Topdown control in a detritusbased food web: fish, shredders, and leaf breakdown. Oecologia, 132: 307-315.

SAIKIA, S. K. 2011. Review on periphyton as mediator of nutrient transfer in aquatic ecosystems. Ecologia Balkanica, 3 (2): 65-78.

SCHROEDER, F., W. TRAUNSPURGER, K. PETTERSSON \& L. PETERS. 2012. Temporal changes in periphytic meiofauna in lakes of different trophic states. Journal of Limnology, 71 (1): 216-227.

SCULTHORPE, C. D. 1967. The Biology of Aquatic Vascular Plants. Edward Arnold, London. UK.

SEMMENS, B. X., E. J. WARD, J. W. MOORE \& C. T. DARIMONT. 2009. Quantifying Inter- and Intra-Population Niche Variability Using Hierarchical Bayesian Stable Isotope Mixing Models. Plos One, 4 (7) e6187: 1-9.

SOTO, D. X., E. GACIA \& J. CATALAN. 2013. Freshwater food web studies: a plea for multiple tracer approach. Limnetica, 32 (1): 97-106.

STOLER, A. B. \& R. A. RELYEA. 2011. Living in the litter: the infl uence of tree leaf litter on wetland communities. Oikos, 120: 862-872.
SWAN, C. M. \& M. A. PALMER. 2006. Composition of speciose leaf litter alters stream detritivore growth, feeding activity and leaf breakdown. Oecologia, 147: 469-478.

TACHET, H., P. RICHOUX, M. BOURNAUD \& P. USSEGLIO-POLATERA. 2002. Invertebrés d'Eau Douce, Second corrected impression. CNRS editions, Paris. France.

TAYLOR, B. E., D. A. LEEPER, M. A. MCCLURE \& A. E. DEBIASE. 1999. Carolina bays: ecology of aquatic invertebrates and perspectives on conservation. In: Invertebrates in Freshwater Wetlands of North America: Ecology and Management D.P. Batzer, R.B. Rader \& S.A. Wissinger (eds.): $167-$ 196. John Wiley \& Sons, NY. USA.

TIMMS, R. M. \& B. MOSS. 1984. Prevention of growth of potentially dense phytoplankton populations by zooplankton grazing, in the presence of zooplanktivorous fish, in a shallow wetland ecosystem. Limnology and Oceanography, 29: 472-486.

VADEBONCOEUR, Y., J. VANDER ZANDEN \& D. M. LODGE. 2002. Putting the lake back together: reintegrating benthic pathways into lake food web models. BioScience, 52: 44-54.

VANDER ZANDEN, M. J., S. CHANDRA, S-Y. PARK, Y. VADEBONCOEUR \& C. R. GOLDMAN. 2006. Efficiencies of benthic and pelagic pathways in a subalpine lake. Canadian Journal of Fisheries and Aquatic Sciences, 63: 2608-2620.

WALTER, J. K., R. E. BILBY \& B. R. FRANSEN. 2006. Effects of Pacific salmon spawning and carcass availability on the caddisfly Ecclisomyia conspersa (Trichoptera: Limnephilidae). Freshwater Biology, 51: 1211-1218.

WARD, E. J., B. X. SEMMENS \& D. SCHINDLER. 2010. Including source uncertainty and prior information in the analysis of stable isotope mixing models. Environmental Science and Technology, 44: 4645-4650.

WARD, E. J., B. X. SEMMENS, D. L. PHILLIPS, J. W. MOORE \& N. BOUWES. 2011. A quantitative approach to combine sources in stable isotope mixing models. Ecosphere, 2 (2) art19: 1-11.

WEBB, K. D. \& W. J. MITSCH. 2001. Macroinvertebrate diversity and abundance in two experimental wetlands from top-down and bottom-up interpretations. In Annual Report (Olentangy River Wetland Research Park) W.J. Mitsch (ed.): 73-80. Ohio State University, Columbus, OH. USA. 
WETZEL, R. G. 2001. Limnology, lake and river ecosystems. Academic Press, CA. USA.

WISSINGER, S. A. 1999. Ecology of wetland invertebrates: synthesis and application for conservation and management. In: Invertebrates in Freshwater Wetlands of North America-Ecology and Management D. P. Batzer, R. B. Rader \& S. A. Wissinger (eds.): 1043-1086. John Wiley \& Sons, NY. USA.

WOODWARD, G. \& A. G. HILDREW. 2002. Food web structure in riverine landscapes. Freshwater Biology, 47: 777-798.

YOSHII, K. 1999. Stable isotope analyses of benthic organisms in Lake Baikal. Hydrobiologia, 411: 145-159. 